\title{
Resenha
}

\section{KRENAK, Ailton. Ideias para adiar o fim do mundo. São Paulo: Editora Companhia das Letras, 2019. 47 p.}

No livro Ideias para adiar o fim do mundo, podemos conhecer um pouco do pensamento de Ailton Krenak, ativista e artista indígena brasileiro. São três conferências dele que foram transcritas e publicadas pela Editora Companhia das Letras. A obra é um sucesso de vendas, talvez pela necessidade que nós temos hoje no Brasil, e no mundo, de desenvolvermos pensamentos ecológicos, dada a velocidade da constatação de que o Planeta Terra está chegando ao fim.

É nesse sentido que Ailton explica sua ideia de adiar o fim do mundo, contando novas histórias. Como fez Sherazade, no livro Mil e uma noites, para retardar sua própria morte $\mathrm{e}$ a de outras mulheres. A cada nova história contada criticamente pelo Krenak, os humanos refletem um pouco mais e têm a possibilidade de repensar a ambição mercadológica pelo lucro a qualquer preço.

Uma primeira questão colocada no livro é a própria noção do que é ser humano, ou seja, o conceito de humanidade. Ailton nos lembra que há somente um pequeno clube de humanos, que se autoconsiderando donos da razão, determinam quem pode e quem não pode entrar no salão de festas. Ele também sustenta a ideia de que a ancestralidade é fundamental para a própria sanidade humana:

Como justificar que somos uma humanidade se mais de $70 \%$ está totalmente alienado do mínimo exercício de ser? A modernização jogou essa gente do campo e da Floresta para viver em favelas e em periferias, para virar mão de obra em centros urbanos. Essas pessoas foram arrancadas de seus coletivos, de seus lugares de origem, e jogadas nesse liquidificador chamado humanidade. Se as pessoas não tiverem vínculos profundos com sua memória ancestral, com as referências que dão sustentação a uma identidade, vão ficar loucas neste mundo maluco que compartilhamos. (KRENAK, 2019, p. 9)

\footnotetext{
${ }^{1}$ Graduado, Mestre e Doutor em Letras pela Universidade Federal de Minas Gerais - UFMG. É poeta e também professor e pesquisador da Universidade do Estado de Minas Gerais - UEMG, Unidade João Monlevade, MG, Brasil. E-mail: rafael.ferreira@uemg.br.
} 
A humanidade está então dividida em humanos e sub-humanos; estes seriam os índios, caiçaras, quilombolas e aborígenes. Para ele, o modo de vida orgânico desses com a terra incomoda os que só podem ver o mundo como um produto.

De uma maneira leve e irônica, bem ao estilo de uma linhagem crítica brasileira (que vai de Oswald de Andrade e Carlos Drummond de Andrade até Viveiros de Castro e Davi Yanomami), Krenak cria um discurso que coloca em xeque o domínio do solo brasileiro por empresas coloniais. Essas grandes corporações "tomam conta da terra" (KRENAK, 2019, p. 11) e ajudam a difundir o mito da sustentabilidade, se colocando como detentoras de um selo verde, ou ambientalmente responsáveis, e, por isso, legitimadas para continuarem a arrancar tudo o que puderem dos recursos minerais. Assim, só sobrariam pequenos parques, que Ailton associa ao parking, onde poderemos estacionar nossos carros. São os humanos considerados, portanto, apenas consumidores e não cidadãos.

Para corroborar seu discurso, o autor lembra da história de seu próprio povo: os Krenak, que vem sofrendo durante séculos com a colonização e, mais recentemente, tiveram seu rio sagrado morto. O rompimento da barragem do Fundão em Mariana, um dos maiores crimes ambientais da história, praticamente matou o rio Watu. Como nos explica Ailton, não se trata de um simples curso de água, ou seja, apenas um recurso, mas:

O rio Doce, que nós, os Krenak, chamamos de Watu, nosso avô, é uma pessoa, não um recurso, como dizem os economistas. Ele não é algo de que alguém possa se apropriar; é uma parte da nossa construção como coletivo que habita um lugar específico, onde fomos gradualmente confinados pelo governo para podermos viver e reproduzir as nossas formas de organização (com toda essa pressão externa). (KRENAK, 2019. p. 21)

Situação dramática que é exposta não como motivo de desesperança e depressão, mas como uma queda do céu, como nos ensina Davi Yanomami, necessária para entendermos que outros mundos existem, e, mais do que isso, que podem suscitar novas possibilidades de reflexões e modos de vida em nossa mãe chamada Planeta Terra. São mundos dentro do mundo, que tornam tudo mais múltiplo e plural do que uma língua, uma religião, uma forma de vida ou um pensamento hegemônico:

Devíamos admitir a natureza como uma imensa multidão de formas, incluindo cada pedaço de nós, que somos parte de tudo: $70 \%$ de água e um monte de outros materiais que nos compõem. E nós criamos essa abstração de unidade, o homem como medida das coisas, e saímos por aí atropelando tudo, num convencimento geral até que todos aceitem que existe uma humanidade com a qual se identificam, agindo no mundo à nossa disposição, pegando o que a gente quiser. (KRENAK, 2019, p. 33) 
Como diriam os pajés Yanomamis, é preciso cantar, dançar, manejar de forma saudável a floresta e os espíritos que nela vivem para que o céu não caia. Ailton conta suas histórias com um prazer de quem gosta de estar vivo no meio dos vivos e não aceita as ausências que nosso mundo consumista nos impõe. Como ele afirma, nosso tempo é pródigo em criar ausências "do sentido de viver em sociedade, do próprio sentido da experiência da vida”. (KRENAK, 2019, p. 13)

\section{REFERÊNCIAS}

KRENAK, Ailton. Ideias para adiar o fim do mundo. São Paulo: Editora: Companhia das Letras, 2019.

KOPENAWA, Davi; ALBERT, Bruce. A queda do céu. Palavras de um xamã Yanomami. Tradução de Beatriz Perrone-Moisés. São Paulo: Companhia das Letras, 2015. 